\section{Polymer Processing for Kyoto Protocol}

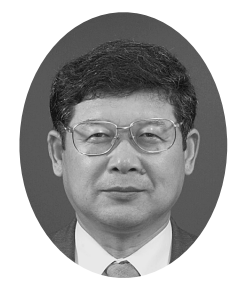

COP 3 (1997) で採択された京都議定書 (Kyoto Protocol) の発効が正式に決定し, 世界各国は温室効果ガス $\left(\mathrm{CO}_{2}\right)$ の削減に向けて対策を本格化する. 日本は，2008-2012 年 に 90 年比 $6 \%$ の温室効果ガス削減を目標とするが 2003 年 の実績推定は 90 年比 $8 \%$ 増であり, 現状では約 $14 \%$ の削 減が必要となる。

プラスチック成形品の LCA (Life Cycle Assessment) を行うと, 他材料に比較して現状では環境負荷の大きいこ とが確認される．環境負荷低減に対しては $3 \mathrm{R}$ (Reduce, Reuse, Recycle）を中心に種々の取り組みが行われている が，プラスチックの成形加工における環境負荷低減・省工 ネも今後は非常に重要となる.

プラスチックの溶融成形加工は, 原料を軟化・溶融, 賦 型, 固化・冷却のプロセスから構成され, 賦型には相変化 が必要であるが, 前後の加熱・冷却では結果的にエネル ギーが無駄に消費されている. 成形機の温度制御や型締め にも，本来不必要なエネルギーを消費していることを再認 識したい。

粉末加工や塑性加工などの革新的なプロセスへの継続的 な挑戦も重要であるが, ここでは本学会の特徵である現場 サイドで展開できる省エネ技術開発に大きく期待したい. 成形プロセスにおける熱資源は, 温度が低い低品位エネル ギーであるが, ヒートポンプにより熱を回収し, 材料乾燥 や部屋空調に使用するなど, 成形工場が Thermal closed loop を構成し, 賦型に使用するエネルギーのみが実質的 に消費されるシステムができれば理想である. シリンダー のせん断熱をペルチェ素子で電気に変換し活用するなど, 未利用熱は目の前にある.

この夢を実現するためには，加工プロセスの詳細なエネ ルギー収支を解析し，本当に必要なエネルギーを明確化す る必要があるが，一方では，工場全体を見渡しエネルギー バランスを考える巨視的な視点が求められる.

電気製品の開発現場に移り, 成形加工の新しい夢が見ら れるようになり，本当に楽しい.

\footnotetext{
* Baba, Fumiaki

三菱電機株) 住環境研究開発センター

鎌倉市大船 5-1-1（テ247-8501）
}

\section{こんな成形機は \\ いかがですか？}

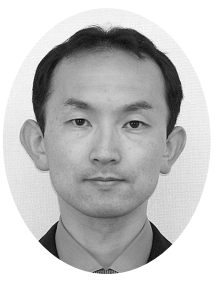

林和 樹*

ある成形工場でのこと。

「Aさん，急いでこの製品を作って下さい.」

「はい?」上司から指示された $\mathrm{A}$ さんは，成形に携わっ てまだ間もない. そんなことを急に言われたって，こんな 複雑な製品を成形の素人がベテランのようにすぐに作り出 せるわけがない，成形機の何をどう調整すれば，より良い 製品が早く取り出せるかまだわからないのに…2005 年 当時であれば当然の反応であったかもしれない.しかし今 は $20 \mathrm{XX}$ 年.「大丈夫だよ. シミュレーションで大体の成 形条件が出ているから,あとはあいつが助けてくれるよ.」 指差した先には，矓しいくらいのオーラに包まれた射出成 形機が.

上司の言葉を信じ，流動解析のシミュレーション結果を 参考におおよその条件で成形を始めた。それから間もなく， 見る見るうちに成形条件が修正され，上司の言葉通りに難 なく製品を作り出す $\mathrm{A}$ さんの姿があった.

執筆のお話しを頂いた際, 以前あるお客様から伺った話 しを思い出した。

「成形の素人が $2 ， 3$ 時間の講習で職人並みの事ができる ような成形機が欲しい.ひとりの社員が成形のノウハウを 身に付けるまでには時間がかかってしまう.」

現在の成形機は高精度 ・高機能化し, 指示した通りの事 を正確に動作出来るようになってきた。しかしそれはあく までも人間が判断し，指示を出した事に対してである。指 示する人間の判断により, 作られる製品は良品にも不良品 にも成りうる. 判断・指示ができれば良いが，最近の複雑 な製品形状や, 多種多様な材質により全ての現象を把握し, 正確な判断を下す事は困難を極める。

これからは，今のような『人間が成形機をコントロール する』ことから，『人間をアシストする成形機一自らが分 析し，人間の判断をアシストする』ことが求められるので はないだろうか. 例えるならば，周囲の危険を分析・判断 し，ブレーキを踏むようにシグナルを送る（人間の動作を アシストする）ようになった自動車のように.

このような人間にとって都合が良い，夢のような成形機 を思い描いてみた（この形がお客様の望む形であれば良い のであるが). 今後この形だけでなく，更にサプライズな 機能を付加してお客様の元に届けられる事を胸に思いつつ 新しい年を迎えるとする。

\footnotetext{
* Hayashi, Kazuki

日精樹脂工業(侏) 技術研究所

長野県埴科郡坂城町南条 2110（衫 389-0693）
} 